\title{
Immune-Monitoring Disease Activity in Primary Membranous Nephropathy
}

\author{
Paolo Cravedi ${ }^{1}$, Marta Jarque $^{2}$, Andrea Angeletti ${ }^{3}$, Àlex Favà $^{2}$, Chiara Cantarelli ${ }^{4}$ and \\ Oriol Bestard ${ }^{2,5 *}$
}

${ }^{1}$ Renal Division, Department of Medicine, Icahn School of Medicine at Mount Sinai, New York, NY, United States, ${ }^{2}$ Experimental Nephrology Laboratory, Biomedical Research Institute of Bellvitge (IDIBELL), Barcelona, Spain, ${ }^{3}$ Nephrology, Dialysis and Renal Transplant Unit, Department of Experimental Diagnostic and Specialty Medicine (DIMES), St. Orsola Hospital, University of Bologna, Bologna, Italy, ${ }^{4}$ UO Nefrologia, Dipartimento di Medicina e Chirurgia, Azienda Ospedaliero-Universitaria Parma, Parma, Italy, ${ }^{5}$ Kidney Transplant Unit, Nephrology Department, Bellvitge University Hospital, Barcelona University, Biomedical Research Institute of Bellvitge (IDIBELL), Barcelona, Spain

OPEN ACCESS

Edited by:

Piergiorgio Messa,

University of Milan, Italy

Reviewed by:

Manuel Praga,

Complutense University of

Madrid, Spain

Richard James Glassock,

UCLA David Geffen School of

Medicine, United States

*Correspondence:

Oriol Bestard

obestard@bel/vitgehospital.cat

$$
\begin{array}{r}
\text { Specialty section: } \\
\text { This article was submitted to } \\
\text { Nephrology, } \\
\text { a section of the journal } \\
\text { Frontiers in Medicine }
\end{array}
$$

Received: 10 July 2019 Accepted: 14 October 2019 Published: 08 November 2019

Citation:

Cravedi $P$, Jarque $M$, Angeletti $A$, Favà À, Cantarelli $C$ and Bestard $O$ (2019) Immune-Monitoring Disease

Activity in Primary Membranous Nephropathy. Front. Med. 6:241.

doi: 10.3389/fmed.2019.00241
Primary membranous nephropathy $(\mathrm{MN})$ is a glomerular disease mediated by autoreactive antibodies, being the main cause of nephrotic syndrome among adult patients. While the pathogenesis of $\mathrm{MN}$ is still controversial, the detection of autoantibodies against two specific glomerular antigens, phospholipase A2 receptor $\left(P\left\llcorner A_{2} R\right)\right.$ and thrombospondin type 1 domain containing 7A (THSD7A), together with the beneficial effect of therapies targeting $B$ cells, have highlighted the main role of autoreactive $B$ cells driving this renal disease. In fact, the detection of $P L A_{2} R-$ specific IgG4 antibodies has resulted in a paradigm shift regarding the diagnosis as well as a better prediction of the progression and recurrence of primary MN. Nevertheless, some patients do not show remission of the nephrotic syndrome or do rapidly recur after immunosuppression withdrawal, regardless the absence of detectable anti-PLA $\mathrm{A}_{2} \mathrm{R}$ antibodies, thus highlighting the need of other immune biomarkers for $\mathrm{MN}$ risk-stratification. Notably, the exclusive evaluation of circulating antibodies may significantly underestimate the magnitude of the global humoral memory immune response since it may exclude the role of antigen-specific memory B cells. Therefore, the assessment of $P\left\llcorner A_{2} R\right.$-specific $B$-cell immune responses using novel technologies in a functional manner may provide novel insight on the pathogenic mechanisms of $B$ cells triggering $\mathrm{MN}$ as well as refine current immune-risk stratification solely based on circulating autoantibodies.

Keywords: membranous nephropathy, glomerulonephritis recurrence, $\mathrm{PLA}_{2} \mathrm{R}$, THSD7A, autoreactive $\mathrm{B}$ cells

\section{INTRODUCTION}

Primary membranous nephropathy $(\mathrm{MN})$ is an autoantibody-mediated glomerular disease that represents one of the leading causes of nephrotic syndrome in adults (1). MN is characterized by the deposition of anti-podocyte targeted IgG antibodies on the subepithelial layer of the glomerular capillary wall. Autoantibodies deposition leads to the thickening of the glomerular basement membrane, complement activation, and glomerular capillary injury with consequent proteinuria. In $\sim 25 \%$ of patients, $\mathrm{MN}$ is classified as "secondary," due to a contemporary detection of a causative disease, such as malignancies, infections, drug reactions, or autoimmune diseases including systemic lupus erythematosus $(2,3)$. The natural history of the untreated disease is 
variable: spontaneous complete remission of primary $\mathrm{MN}$ is observed in approximately the $30-40 \%$ of patients $(4,5)$, whereas $30 \%$ of cases develop end-stage kidney disease (ESKD) generally over 10-15 years $(6,7)$. In kidney transplant recipients, $\mathrm{MN}$ relapses appear in $10-45 \%$ of cases $(8-12)$ and occur as a de novo disease in about $2 \%$ of recipients $(13,14)$.

Current understanding of MN pathophysiology comes from studies in rodent models. In 1959, Heymann et al. (15) described a model of MN, now defined as active Heymann nephritis, which was induced by immunizing Lewis rats with intraperitoneal injections of crude kidney extracts, together with complete Freund's adjuvant. This resulted in a disease characterized by subepithelial immune complexes similar to human MN. Subsequent in vivo and in vitro studies have led to a better understanding of how subepithelial immune deposits lead to podocyte injury and proteinuria. Complement-mediated cytotoxicity plays a major role in the disease pathogenesis, especially the terminal complement complex C5b-9 (membrane attack complex-MAC), which is detectable in the urine of patients with $\mathrm{MN}$ and considered a marker of podocytes injury (16-20). Data suggest that in primary MN, complement cascade is firstly activated by the mannose binding lectin pathway, leading to the formation of $\mathrm{C} 3$ deposits in the subepithelial space along with MAC on podocyte membranes (21-23).

The identification of the cell surface protease neutral endopeptidase (NEP) as a target podocyte autoantigen in a newborn with $\mathrm{MN}$ represented a cornerstone in our understanding of MN pathophysiology. Pierre Ronco and Hanna Debiec described the case of a mother genetically deficient in NEP that had given birth to an infant who developed antenatal nephrotic syndrome (24). During the previous pregnancy, the mother generated circulating anti-NEP that crossed the placenta and targeted NEP on the fetal kidney during her subsequent pregnancy, leading to in situ immune deposits. Therefore, NEP represents the first podocyte protein demonstrated to be a target antigen in human $\mathrm{MN}$ (25).

Identification of autoantibodies reactive against $\mathrm{M}$-type phospholipase $\mathrm{A} 2$ receptor type $1\left(\mathrm{PLA}_{2} \mathrm{R}\right)(26)$ and, later, against thrombospondin type 1 domain containing 7A (THSD7A) (27), two podocyte-expressed proteins, represented a further major step forward in defining the disease pathogenesis. Autoantibodies against such antigens can be detected in the $75-85 \%$ of primary $\mathrm{MN}$ patients $(28,29)$ : anti-PLA $\mathrm{PL}_{2} \mathrm{R}$ autoantibodies are present in $\sim 70-80 \%$ of adult cases, particularly in men $(26,30)$, whereas anti-THSD7A antibodies may be detected in only $3-5 \%$ of adults with primary $\mathrm{MN}$, mainly in women $(27,31)$. Only about $1 \%$ of $\mathrm{MN}$ patients have both anti-PLA $2 \mathrm{R}$ and anti-THSD7A autoantibodies detectable (32).

A 2019 study (33) showed that, in MN patients without detectable anti-PLA 2 R or anti-THSD7A autoantibodies, exostosin1/exostosin 2 could represent target antigens. The authors performed mass spectrometry on laser microdissected glomeruli and immunohistochemistry on kidney biopsy of 22 MN patients, including 7 with anti-PLA 2 R antibodies and 15 without, detecting exostosin $1 /$ exostosin 2 expression uniquely in five cases without detectable circulating anti-PLA 2 R antibodies. In a larger cohort of $209 \mathrm{MN}$ patients negative for circulating
anti-PLA ${ }_{2} \mathrm{R}$ antibodies, immunohistochemistry revealed bright granular glomerular basement membrane staining for exostosin 1 /exostosin 2 in 16 cases (33). Eleven of the 16 cases showed signs of lupus nephritis or autoimmunity, suggesting that exostosin 1/exostosin 2 may represent a potential marker of a specific subtype of $\mathrm{MN}$, most commonly associated with autoimmune diseases (33).

Altogether, these mechanistic findings have highlighted the key role of $\mathrm{B}$ cells in the pathogenesis of $\mathrm{MN}$, both as autoantibody producing cells (34) and as antigen presenting cells (35), thus providing the basis for B-cell target therapies (36-39). However, response to such therapies remains unpredictable and the identification of subjects who would develop spontaneous remission (in whom immunosuppression could be avoided) is still very challenging. The discovery of $\mathrm{MN}$-specific antigens has allowed the development of many diagnostic and prognostic serologic tests and optimal non-invasive biomarkers for monitoring disease activity. Nevertheless, while the assessment of autoantibodies provides useful information about the humoral memory immune response, other assays are needed to better immune-risk stratify patients and to tailor treatment in a personalized fashion.

\section{CURRENT CLINICAL MN BIOMARKERS: SERUM CREATININE, URINARY PROTEIN AND KIDNEY BIOPSY}

According to the most recent Controversies Conference on KDIGO guidelines (39), proteinuria, and serum creatinine are still considered the gold-standard biomarkers to riskstratify MN patients. For instance, individuals with subnephrotic proteinuria have excellent long-term renal survival, therefore, immunosuppression is not recommended (39). Conversely, in patients with proteinuria above $4-5 \mathrm{~g} / 24 \mathrm{~h}$, MN prognosis may range from spontaneous remission to development of ESKD.

Urinary markers of renal tubular damage, such as, Beta2 microglobulin, N-acetyl- $\beta$-D-glucosaminidase (NAG) and retinol-binding protein (RBP), kidney injury molecule 1 (KIM1) and neutrophil gelatinase-associated lipocalin (NGAL) have been also proposed to risk-stratify patients with MN. Yet, the levels of these biomarkers seem to not correlate with the severity of the disease (40).

Despite its invasive nature, kidney biopsy is still important for the diagnosis of $\mathrm{MN}$, in particular among patients with altered kidney function and evidence of possible secondary causes (41), but the capacity of histological lesions to predict outcomes or response to therapy is limited at best. Hence, new approaches to better risk-stratify $\mathrm{MN}$ patients are highly needed in the clinical setting.

\section{TARGET ANTIGENS IN MN}

Over the last decade, discovery of target podocyte antigens and the development of commercial assays for the detection of serum anti-PLA 2 R and anti-THSD7A autoantibodies has revolutionized the traditional algorithms for diagnosis and 
management of $\mathrm{MN}$, particularly due to their high specificity for disease diagnosis $(26,27)$. Such autoreactive antibodies recognize the target conformational epitopes on the membrane protein expressed on glomerular podocytes under non-reducing conditions and are predominantly of the IgG4 subclass. Importantly, both autoantibodies are emerging as clinical biomarkers to predict outcome in $\mathrm{MN}$ patients.

\section{Thrombospondin Type 1 Domain Containing 7A (THSD7A)}

THSD7A is a large transmembrane glycoprotein expressed by podocytes. In Europe and United States only 3\% of $\mathrm{MN}$ subjects expresses anti-THSD7A autoantibodies (predominantly IgG4), while it increases to a $9 \%$ in Japan (27, 31, 42, 43). Importantly, anti-THSD7A antibodies induce a MN-like pattern of disease when injected in mice (29). In a recent retrospective study, Zaghrini et al. (44) developed a new ELISA assay to detect THSD7A-specific antibodies: levels of antiTHSD7A autoantibodies correlated with disease activity and with response to treatment. Also, patients with high titers at baseline had a poorer clinical outcome. I has also been reported an association between anti-THSD7A autoantibodies and malignancies $(42,43,45)$, but this needs to be better clarified in larger, multicenter studies.

\section{Phospholipase A2 Receptor Type 1 (PLA 2 R)}

The M-type phospholipase A2 receptor $\left(\mathrm{PLA}_{2} \mathrm{R}\right)$ is one of four members of the mannose receptor in mammals (46). PLA 2 is a multifunctional receptor for soluble phospholipase A2 (sPLA2), which is described as a pro-inflammatory enzyme and $\mathrm{PLA}_{2} \mathrm{R}$ acts as a scavenger receptor to remove secreted PLA2 enzyme (47). Despite this receptor being highly expressed by human podocytes as well as by neutrophils and alveolar type II epithelial cells $(26,48,49)$, autoantibodies against $\mathrm{PLA}_{2} \mathrm{R}$ exclusively induce nephrotic syndrome without apparent impairment in other organs.

The complexity of the $\mathrm{PLA}_{2} \mathrm{R}$ structure is illustrated by the identification of distinct immunogenic $\mathrm{PLA}_{2} \mathrm{R}$ epitopes, including a cysteine-rich domain (CysR), a fibronectin type II domain and eight distinct C-type lectin domains (CTLD1-8) (50), which are dependent on the protein conformation (26). Main antigenic epitopes recognized by anti-PLA $\mathrm{A}_{2} \mathrm{R}$ antibodies have been recently identified and reported to be sensitive to reducing agents, thus confirming that conformational structure is of great importance in $\mathrm{PLA}_{2} \mathrm{R}$ epitopes $(51,52)$. A further dominant epitope of $\mathrm{PLA}_{2} \mathrm{R}$ (P28mer) was recently identified being also a dominant epitope of THSD7A in the N-terminal domain, suggesting that this shared motif could be involved in the initial B-cell activation in MN (53).

\section{GENETIC SUSCEPTIBILITY AND HUMORAL AUTOIMMUNE RESPONSE IN MN}

A genetic predisposition for $\mathrm{MN}$ was initially speculated by the associative evidence linking variants in the HLA locus and the risk of developing $\mathrm{MN}$ (54). Years later, family case reports of $\mathrm{MN}$ were also described (55).

Several genome-wide association studies (GWAS) have recently associated risk alleles in HLA genes with the increase risk of MN. Stanescu et al. (56) defined the association between HLADQA1 allele with MN in Caucasian individuals, suggesting that the interaction between sequence variations in immune-proteins and glomerular components may explain a trigger-target model in the disease development. Such interaction between $\mathrm{PLA}_{2} \mathrm{R}$ and HLA-DQA1 variants was also studied in an Asian cohort with similar results (57). More studies confirmed this association in different cohorts of $\mathrm{MN}$ patients (58-61), but the related mechanisms remain unknown.

The possible role of specific HLA alleles in MN was further investigated in two recent studies. Cui et al. (62) genotyped HLA-DRB1, DQA1, DQB1, and DPB1 genes in 261 primary $\mathrm{MN}$ patients and in 599 healthy controls. These investigators confirmed that risk alleles of HLA-DQA1 and $\mathrm{PLA}_{2} \mathrm{R}$ are significantly associated with the susceptibility to MN. Particularly, authors showed that these risk alleles are associated with the presence of circulating anti-PLA 2 antibodies as well as to the increased expression of $\mathrm{PLA}_{2} \mathrm{R}$ in the glomeruli. Authors also detected the classical DRB1*1501 and DRB1*0301 alleles, showing significant independent effects on the risk of $\mathrm{MN}$ among the ethnic group of Han Chinese. Le et al. (63) sequenced HLA locus in 99 anti-PLA 2 R-positive MN subjects and in 100 healthy controls. Again, the association between DRB1*1501 and anti-PLA $\mathrm{A}_{2} \mathrm{R}$ positive $\mathrm{MN}$ was demonstrated, and suggested DRB3*0202 as new risk allele for MN. These two alleles were subsequently confirmed in an independent cohort of 285 controls and 293 cases. Although DRB1*1502 was not revealed as a risk allele for $\mathrm{MN}$, it was associated with significantly higher levels of anti-PLA 2 R autoantibodies and a significantly increased risk of progression to ESKD (64).

Altogether, GWAS has provided robust data about the genetic susceptibility to $\mathrm{MN}$, suggesting that genetic tests could become a non-invasive tool to risk-stratify $\mathrm{MN}$ patients (65), although more data testing these associations in different ethnic groups are needed (66).

\section{IMMUNE-MONITORING OF AUTOREACTIVE ANTIBODIES}

\section{Detection of PLA 2 R Antigen in the Kidney}

Anti-PLA 2 R IgG4 autoantibodies are detected in the subepithelial immune deposits using immunofluorescence or immunohistochemistry in patients with primary MN (67). In normal kidneys or other glomerular diseases, the $\mathrm{PLA}_{2} \mathrm{R}$ antigen is weakly expressed on the podocyte surface (67). Generally, a strong association between glomerular $\mathrm{PLA}_{2} \mathrm{R}$ staining and circulating anti-PLA ${ }_{2} \mathrm{R}$ antibodies is found $(28$, $60,68)$, particularly when autoantibody levels are measured at the time of the biopsy assessment (69). However, glomerular $\mathrm{PLA}_{2} \mathrm{R}$ staining is not considered a diagnostic test for active disease, since the positivity of glomerular $\mathrm{PLA}_{2} \mathrm{R}$ staining with undetectable circulating anti-PLA ${ }_{2} \mathrm{R}$ autoantibodies is unlikely 
$(28,69,70)$ and may reflect an immunologically inactive disease as a positive $P L A_{2} R$ antigen can persist for weeks or months after remission (67).

\section{Detection of Serum Anti-PLA 2 R Autoantibodies as a Diagnostic Tool}

Western blotting was initially performed to detect anti-PLA ${ }_{2} \mathrm{R}$ (26) and anti-THSD7A (27) autoantibodies, but this test is inadequate for routine clinical use. The first commercially available assay for serum anti-PLA ${ }_{2} \mathrm{R}$ autoantibodies detection was an indirect immunofluorescence assay (CBA-IFA; Euroimmun, Luebeck, Germany), based on a semi-quantitative determination, and therefore, not ideal for monitoring therapeutic response and disease progression. Most clinical laboratories routinely use an ELISA-based assay (Euroimmun), because it is able to quantify anti-PLA $\mathrm{P}_{2} \mathrm{R}$ autoantibodies, but this assay is not as sensitive as CBA-IFA assays. Conversely, the CBA-IFA anti-PLA ${ }_{2} \mathrm{R}$ immunoassays detection may be considered only when diagnosis of $\mathrm{PLA}_{2} \mathrm{R}$-associated $\mathrm{MN}$ is strongly suspected, but there is a negative ELISA test. The most recent diagnostic assay is a laser bead immunoassay (ALBIA; Mitogen Advanced Diagnostics Laboratory, Calgary, Canada), that allows a sensitive and a quantitative detection of these autoantibodies. This assay allows the detection of different molecules such as antibodies, complement or cytokines. A comparison between the CBA-IFA, ELISA and ALBIA platforms, showed similar capacity across the different tests to detect anti-PLA ${ }_{2} \mathrm{R}$ autoantibodies (71).

\section{Serum Anti-PLA $\mathbf{A}_{2}$ Autoantibodies as a Risk-Prognostic Biomarker of MN}

Different groups have suggested the use of anti-PLA ${ }_{2} \mathrm{R}$ autoantibodies to predict spontaneous remission of MN. Hofstra et al. (72) reported that spontaneous remission is inversely related to high antibodies titers measured by up to 6 months after biopsy assessment. Similarly, Timmermans et al. (73) showed that, among $109 \mathrm{MN}$ patients, subjects with detectable serum anti-PLA ${ }_{2} \mathrm{R}$ autoantibodies at the time of biopsy had a lower probability for spontaneous remission than seronegative patients. In a retrospective study including 68 patients with biopsy-proven $\mathrm{MN}$, Jullien et al. (74), reported that spontaneous remission was correlated with low titers of anti-PLA $\mathrm{A}_{2} \mathrm{R}$ autoantibody at time of biopsy. These data were recently confirmed by a prospective study involving $62 \mathrm{MN}$ patients: complete spontaneous remission was more common in subjects with lower anti-PLA ${ }_{2} \mathrm{R}$ autoantibody levels at the time of diagnosis $(<40$ $\mathrm{UI} / \mathrm{mL})(75)$.

Beck et al. (76) evaluated the relationship between changes in serum PLA 2 R-specific autoantibodies levels and the response to $\mathrm{B}$ cell-depleting antibody rituximab therapy in 35 adult patients with MN. Circulating autoantibodies were detected in $71 \%$ of patients at baseline and levels decreased after rituximab therapy in the majority of them. The reduction of anti$\mathrm{PLA}_{2} \mathrm{R}$ autoantibody levels anticipated the decline of proteinuria, and in one particular patient with a relapse of proteinuria, the reappearance of the autoantibody in serum preceded the recurrence of $\mathrm{MN}$. However, proteinuria may persist, regardless the presence of autoreactive anti-PLA $\mathrm{P}_{2} \mathrm{R}$ antibodies due to irreversible capillary wall injury thus, perpetuating albuminuria levels in absence of active autoimmunity.

More recently, Ruggenenti et al. (77) investigated the association between treatment effect, circulating anti-PLA ${ }_{2} \mathrm{R}$ autoantibodies and genetic polymorphisms predisposing to antibody production in $132 \mathrm{MN}$ patients with nephrotic range proteinuria treated with rituximab. Outcome of patients with or without detectable anti-PLA $A_{2} \mathrm{R}$ autoantibodies at baseline were similar. However, among 81 patients with autoantibodies, lower anti-PLA $\mathrm{A}_{2} \mathrm{R}$ autoantibodies titer at baseline and full depletion at 6 months post-treatment strongly predicted remission over a median follow-up period of 30.8 months. All 25 patients displaying complete remission were preceded by undetected anti-PLA 2 R autoantibodies in circulation, while reemergence of circulating antibodies predicted clinical disease relapse. Accordingly, a further study involving 30 patients with $\mathrm{MN}$ and elevated anti-PLA $\mathrm{P}_{2} \mathrm{R}$ autoantibodies (78) showed that clinical remission was heralded by a reduction in circulating autoantibodies.

Collectively, the above studies and further published data (7983) suggest that serial measurements of anti-PLA ${ }_{2} \mathrm{R}$ autoantibody titers in the serum may help at risk-stratifying patients, allowing to personalize treatment and to reduce the side-effects related to over-immunosuppression.

However, antigen-specific memory $B$ cells may exist and be ready to develop a rapid and effective secondary immune response even in absence of detectable circulating autoantibodies. This suggests that the assessment of the humoral auto-immune response using other cell-based assays may significantly improve the understanding of the effector mechanisms of the disease in patients with primary $\mathrm{MN}$.

\section{$\mathrm{PLA}_{2} \mathrm{R}$ Epitope Spreading and Disease Progression}

Epitope spreading is a common immunopathogenic response to self-antigens: the immune response primary involves the so-defined immunodominant epitope recognized by most autoantibodies, then expands to the intramolecular epitope on the same protein (intramolecular epitope spreading) or to dominant epitopes on neighboring molecules (intermolecular epitope spreading) $(84,85)$. The result is an increased diversity in antibody repertoire, leading to a broader overall immune response. Epitope spreading for the CysR epitope of $\mathrm{PLA}_{2} \mathrm{R}$ has been recognized as independent risk factor for reduced renal survival (86). In the GEMRITUX (Evaluate Rituximab Treatment for Idiopathic Membranous Nephropathy) randomized controlled trial (87), including a cohort of 58 patients positive for anti-PLA $\mathrm{A}_{2} \mathrm{R}$-specific autoantibodies randomly treated with rituximab or conservative therapy, epitope spreading strongly correlated with serum titer of anti-PLA 2 R autoantibodies The absence of epitope spreading at onset was an independent predictor of remission at 6 months and at last follow-up (median of 23 months) (88). Of interest, 10 of the 17 patients 
TABLE 1 | Studies on the immune phenotype of patients with membranous nephropathy.

\begin{tabular}{|c|c|c|c|}
\hline Reference & Patients' characteristics (number) & Assay/biomarkers & Results \\
\hline Ozaki et al. (89) & $\begin{array}{l}\text { MN (30): } \\
\text { - Untreated, } \\
\text { - with Prednisolone, } \\
\text { - incomplete remission, } \\
\text { - complete remission }\end{array}$ & $\begin{array}{l}\text { Flow cytometry/ Helper, } \\
\text { suppressor T cells }\end{array}$ & $\begin{array}{l}\text { - Untreated nephrotic patients showed a significant } \\
\text { decreased in suppressor T cell levels and a relative } \\
\text { increase in helper T cells. } \\
\text { - Prednisolone-treated patients showed an increased } \\
\text { number of suppressor T cells. }\end{array}$ \\
\hline Wang et al. (90) & $\begin{array}{l}\text { MN (66): - No previous IS } \\
\text { HC (40) }\end{array}$ & $\begin{array}{l}\text { Flow cytometry/ Treg, B and } \\
\text { T cells }\end{array}$ & $\begin{array}{l}\text { - Treg cells were decreased in MN patients. } \\
\text { - B cells were increased in MN patients. } \\
\text { T cells }\left(\mathrm{CD} 4^{+} / \mathrm{CD} 8^{+}\right) \text {were increased in MN patients. } \\
\text { - No association between circulating B cells and } \\
\text { disease activity. }\end{array}$ \\
\hline Cagnoli et al. (91) & $\begin{array}{l}\text { MN (27) } \\
\text { - 12/27 nephrotic syndrome, } \\
\text { - 6/27 isolated proteinuria, } \\
\text { - 9/27 complete remission }\end{array}$ & $\begin{array}{l}\text { Indirect IF/ Total peripheral T } \\
\text { cells, } \mathrm{CD}^{+}{ }^{+} \text {, and } \mathrm{CD}^{+} \mathrm{T} \\
\text { cells }\end{array}$ & $\begin{array}{l}\text { - Patients with } \mathrm{MN} \text { and nephrotic syndrome presented a } \\
\mathrm{CD} 4^{+} / \mathrm{CD} 8^{+} \text {ratio greater than the control group due } \\
\text { to a reduction of } \mathrm{CD}^{+} \mathrm{T} \text { cell subset. }\end{array}$ \\
\hline
\end{tabular}

Indirect IF/ Total peripheral T cells (LEU4), helper T cells (LEU3a), cytotoxic T cells (LEU2a)

Suppressor cell function evaluation due to response to Concanavalin $\mathrm{A}$

Intracellular cytokine assay by flow cytometry/T-helper cells, Th1 and Th2 cytokines

$\begin{array}{ll}\text { Hirayama et al. } & \text { MN (8): } \\ \begin{array}{ll}\text { (94) } & - \text { Proteinuria ranging from } 2 \text { to } 7 \mathrm{~g} / \text { day } \\ & - \text { Creatinine clearance }>100 \\ & \mathrm{ml} / \mathrm{min} / 1.73 \mathrm{~m}^{2} \mathrm{HC} \mathrm{(23)}\end{array}\end{array}$

$\begin{array}{ll}\text { Masutani et al. (95) } & \text { MN (24) } \\ & \text { MCD (13) } \\ & \text { FSGS (12) } \\ & \text { HC (51) }\end{array}$

Kuroki et al. (96) MN (14)

HC (14)

Intracellular cytokine assay by flow cytometry/ T-helper cells, Th1 and Th2 cytokines

Flow cytometry/ T cells, T-helper cells, T-cytotoxic cells, B cells Real-time PCR/ Th1 and Th2 cytokines

Flow cytometry/ T, B and NK cells

- Patients were all treated with Rituximab

- Creatinine clearance $\geq 30 \mathrm{ml} / \mathrm{min} / 1.73$ $\mathrm{m}^{2}$

- Persistent proteinuria >5 g/24 h

Roccatello et al. (98)
MN (17) - Patients were all treated with rituximab
Flow cytometry/B, T, Treg cells

ELISA assay/IL-35 and $P L A_{2} R$ antibodies
- Helper/cytotoxic T cell ratio was significantly higher at baseline in MN patients than the in controls due to a reduction of LEU2 cell subset.

- Baseline helper/cytotoxic T cell ratio was significantly higher in patients achieving remission as compared to non-responder patients.

- Significant reduction in lymphocyte transformation in each group of patients as compared to the control group.

- Suppressor cell function was decreased in each group of patients as compared to the control group.

- Percentages of IL-2+CD4 ${ }^{+} \mathrm{T}$ cells were significantly lower in MN patients than in the controls.

- No differences in percentages of IFN- $\gamma^{+} \mathrm{IL}-4^{+} \mathrm{CD} 4^{+} \mathrm{T}$ cells were observed between different groups.

- Percentages of IL-10+CD4+ T cells were significantly higher in MN patients than in the control group.

- Percentages of IL-4 in MN patients were significantly higher than in the other groups.

- Th1/Th2 ratio was significantly lower in MN patients than in the other groups.

- Percentages of IL-4 correlated with the amount of proteinuria in $\mathrm{MN}$ patients.

- CD4/CD8 cell ratio was higher in MN patients than in the control group, although numbers of $\mathrm{T}$ and $\mathrm{B}$ cells were similar to the control group.

- IL-10 and IL-13 mRNA expression levels was higher in MN patients.

- IL-4 enhances in vitro production of IgG4 by B cells in $\mathrm{MN}$.

- After rituximab treatment, proteinuria decreased and creatinine clearance increased.

- None of the T-reg subset analyses showed significant quantitative differences.

- Baseline quantification of lymphocyte subpopulations did not predict response to rituximab therapy.

- After rituximab treatment, proteinuria decreased and serum creatinine remained stable during the follow-up.

- Treg percentages were significantly higher after treatment as compared to baseline. 
TABLE 1 | Continued

\begin{tabular}{|c|c|c|c|}
\hline Reference & Patients' characteristics (number) & Assay/biomarkers & Results \\
\hline $\begin{array}{l}\text { Rosenzwajget al. } \\
\text { (99) }\end{array}$ & $\begin{array}{l}\text { MN (25): } \\
\text { - 16/25 were treated with NIAT + } \\
\text { rituximab } \\
\text { - } 9 / 25 \text { were treated with NIAT alone } \\
\text { HC (27) }\end{array}$ & $\begin{array}{l}\text { Flow cytometry/ B, T, NK, } \\
\text { Treg, } \gamma \delta \text {-T cells } \\
\text { Multiplex to detect several } \\
\text { cytokines/ chemokines }\end{array}$ & $\begin{array}{l}\text { - Percentages of switched }\left(\mathrm{IgD}-\mathrm{CD} 27^{+}\right) \text {and non- } \\
\text { switched }\left(\mathrm{lgD} \mathrm{C}^{+} \mathrm{CD} 27^{+}\right) \text {memory B cells were higher in } \\
\mathrm{MN} \text { patients due to a higher percentage of naïve B cells } \\
\text { at baseline. } \\
\text { - Treg percentages were lower in MN patient at baseline. } \\
\text { - After rituximab treatment, responder patients to } \\
\text { treatment showed a significantly increased percentage } \\
\text { of Treg cells than non-responders. }\end{array}$ \\
\hline
\end{tabular}

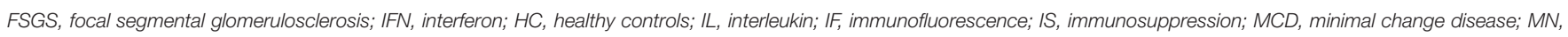
membranous nephropathy; NIAT, nonimmunosuppressive antiproteinuric treatment; NK, natural killer; Treg, regulatory T cells.

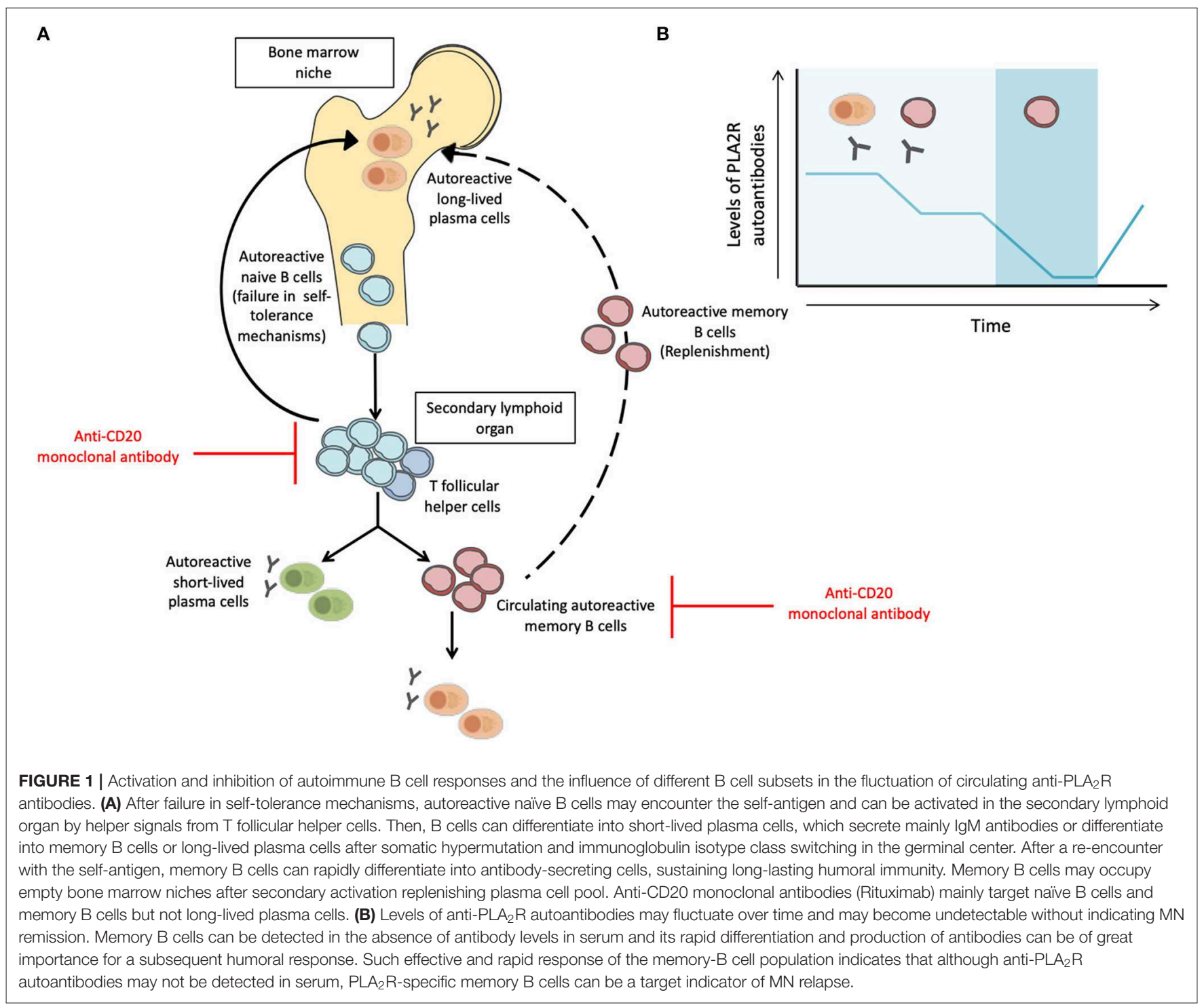

who had epitope spreading at baseline and were treated with rituximab, showed reversal of epitope spreading at 6 months (88). The anti-PLA 2 R autoantibody titer has been shown to correlate with the degree of epitope spreading (88). Therefore, due to the lack of epitope-specific assays for anti-PLA $A_{2} R$ autoantibodies for clinical practice, the total titer of anti-PLA $\mathrm{A}_{2} \mathrm{R}$ autoantibodies could be considered a surrogate of epitope spreading (88). 


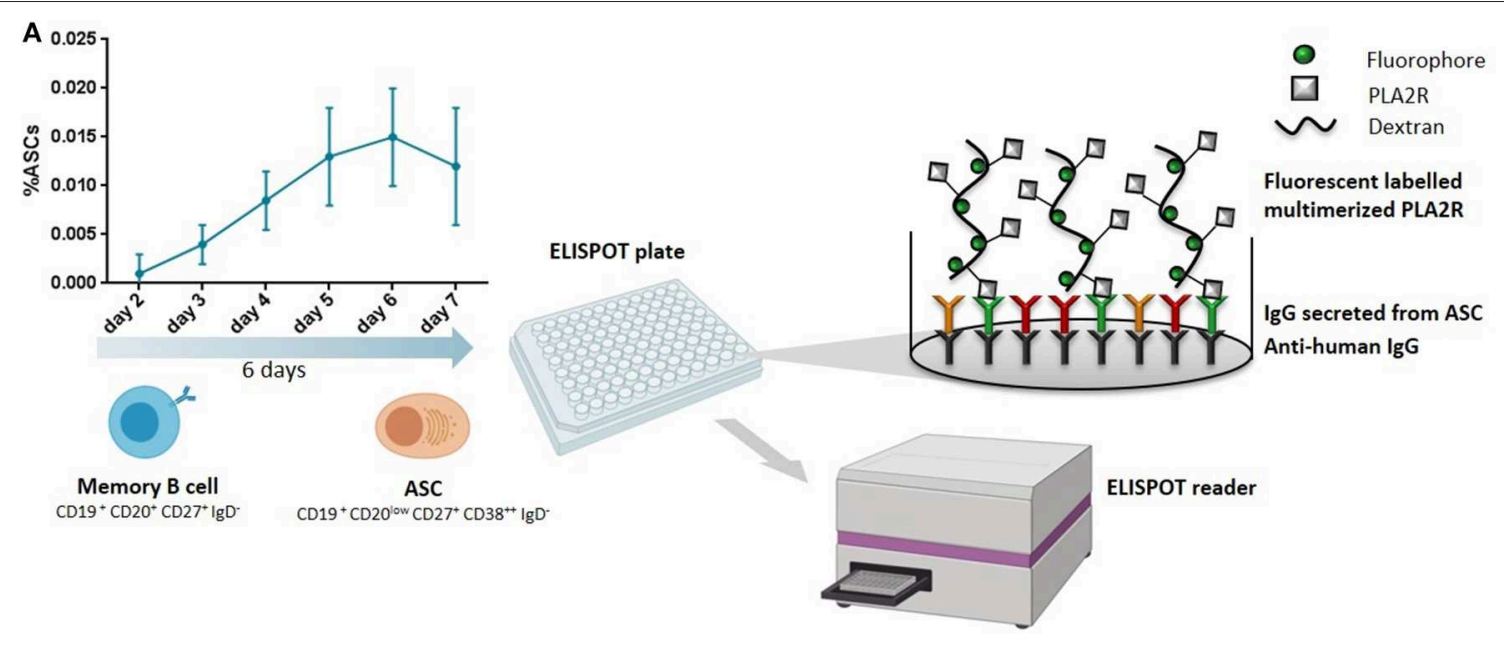

B

\begin{tabular}{|c|c|c|}
\hline & Patient \#1 & Patient \#2 \\
\hline $\begin{array}{l}\text { Proteinuria } \\
\text { (g/24h) }\end{array}$ & 2.3 & 2.5 \\
\hline $\begin{array}{l}\text { Anti-PLA } \mathrm{R}_{2} \mathrm{Ab} \\
\text { Levels (RU/ml) }\end{array}$ & 205 & 215 \\
\hline $\begin{array}{l}\text { PLA }_{2} \text { R-specific } \\
\text { Spots (ELISPOT) }\end{array}$ & & \\
\hline
\end{tabular}

FIGURE 2 | Measuring anti-PLA 2 R reactive memory B cells. (A) Peripheral blood mononuclear cells are first polyclonally activated for 6 days to expand the pool of memory B cells and antibody secreting cells (ASC). Expanded cells are next used for an enzyme-linked immune absorbent spot (ELISPOT) assay to detect cells producing antibodies against PLA $R$. (B) Two representative patients with membranous nephropathy and similar levels of proteinuria and circulating anti-PLA $R$ antibodies. Patient \#1 has a positive ELISPOT, indicating the presence of autoreactive memory B cells (sign of active disease), while Patient \#2 has no detectable autoreactive memory B cells (indicative of a remission phase). Adapted from Luque et al. (112).

\section{Immune Cell Phenotyping and Circulating Cytokines in MN}

\section{Non-antigen-specific Cell Subset Measurements}

A few studies have investigated the immune phenotype of $\mathrm{MN}$ patients and its changes in relation to treatment (Table 1). Some investigators reported an increase of the $\mathrm{CD}^{+} / \mathrm{CD}^{+} \mathrm{T}$ cell ratio in $\mathrm{MN}$ patients with or without nephrotic proteinuria $(89,90)$. Some evidence has shown a reduction of $\mathrm{CD}^{+} \mathrm{T}$ cells in patients with $\mathrm{MN}$ and nephrotic syndrome when compared to healthy subjects (91). This broad phenotype seems to be associated with a more favorable prognostic response to classical immunosuppressive therapy (92), but not to anti-CD20 depletion (93). MN is characterized by a predominance of IgG4 subclass autoantibodies, thus suggesting an involvement of a Th2 immune response, which has been described in some series (94-96).

Interestingly, despite the well-reported role of regulatory T-cells (Treg) in autoimmune diseases (100, 101), limited studies have investigated the role and impact of Tregs in primary MN, with controversial results (97, 98). Recently, Rosenzwajg et al. (99) measured 33 lymphocyte subpopulations and also 27 serum cytokines/chemokines in $25 \mathrm{MN}$ patients and 27 healthy subjects at the time of biopsy. After rituximab treatment, responder patients to treatment showed a significantly increased percentage of Tregs than non-responders concluding that monitoring $\mathrm{T}$-cell subset could be a potential biomarker of $\mathrm{MN}$ activity. 


\section{Cellular Assays Measuring Antigen-Specific Immune Responses}

The discovery of anti-PLA ${ }_{2} \mathrm{R}$ and anti-THSD7A autoantibodies represented a paradigm shift for the diagnosis and management of MN patients. Taking into account the putative pathogenic role of anti-PLA ${ }_{2} \mathrm{R}$ autoantibodies and the efficacy of $\mathrm{B}$ cell depleting therapies $(77,102-104)$, it is reasonable to speculate that autoreactive memory B cells play a fundamental pathogenic role in $\mathrm{MN}$ by fueling a persistent IgG4-specific humoral immune response. However, levels of anti-PLA $2 \mathrm{R}$ autoantibodies fluctuate over time despite persistent renal injury, suggesting that the evaluation of anti-PLA ${ }_{2} \mathrm{R}$ autoantibodies alone may not capture the global humoral immune response taking place in patients with primary $\mathrm{MN}(69,79-81)$. Once B cells recognize the target antigen through the help of autoreactive $\mathrm{T}$ Follicular Helper $\left(\mathrm{T}_{\mathrm{FH}}\right)$ cells, B cells can differentiate into short-lived plasmablasts (secreting manly low-affinity IgM antibodies) or into memory B cells (mBC) and long-lived plasma cells after undergoing somatic hypermutation and immunoglobulin isotype class switching in the germinal center. In case of persistence of the priming antigen and T-cell help, auto-reactive $\mathrm{mBC}$ can rapidly differentiate into antibody-secreting cells and produce the effector antibodies against the specific target antigen and may finally occupy empty bone marrow niches after secondary activation replenishing plasma cell pool $(105,106)$. Noteworthy, autoreactive memory B cells can be detected in absence of autoantibody levels in serum and its rapid differentiation and production of antibodies can be of great importance for a subsequent humoral response (Figure 1) (107, 108). Recent works in kidney transplantation have shown the value of measuring circulating allospecific $\mathrm{mBC}$ in a functional manner, especially in the absence of detectable alloantibodies in the serum (109-111).

Starting from this background, our group has recently developed a new approach to functionally evaluate the $\mathrm{PLA}_{2} \mathrm{R}$ specific $\mathrm{mBC}$ response in $\mathrm{MN}$ patients. Using a $\mathrm{PLA}_{2} \mathrm{R}$-specific $\mathrm{B}$-cell ELISPOT-based immune assay, we have been able to accurately detect circulating $\mathrm{mBC}$ capable of producing anti$\mathrm{PLA}_{2} \mathrm{R}$-specific antibodies at the time of the flare of disease activity, thus confirming the presence of an active humoral immune response (personal communication). While evaluating $\mathrm{PLA}_{2} \mathrm{R}$-specific antibody-secreting cell frequencies using an ELISPOT-based assay allows for an accurate detection of $\mathrm{mBC}$ responses at the single cell level after a polyclonal $\mathrm{mBC}$ culture

\section{REFERENCES}

1. Glassock RJ. The pathogenesis of idiopathic membranous nephropathy: a 50-years odyssey. Am J Kidney Dis. (2010) 56:157-67. doi: 10.1053/j.ajkd.2010.01.008

2. Jennette JC, Iskandar SS, Dalldorf FG. Pathologic differentiation between lupus and non-lupus membranous glomerulopathy. Kidney Int. (1983) 24:377-85. doi: 10.1038/ki.19 83.170

3. Hofstra JM, Fervenza FC, Wetzels JF. Treatment of idiopathic membranous nephropathy. Nat Rev Nephrol. (2013) 9:443-58. doi: $10.1038 /$ nrneph.2013.125 stimulation, anti-PLA ${ }_{2}$ R-specific antibodies may also be detected from these cell culture supernatants using single-antigen beads immune assay. Figure 2 shows two representative patients with similar proteinuria and anti-PLA $2 \mathrm{R}$ autoantibody levels. While the first patient with detectable autoreactive $\mathrm{mBC}$ is having a disease flare, the second one has no detectable autoreactive $\mathrm{mBC}$ and is therefore predicted to undergo remission. If properly validated, this assay may be used to differentiate patients for whom therapy is needed vs. those who will undergo spontaneous remission.

\section{CONCLUSIONS}

Primary $\mathrm{MN}$ is the main cause of nephrotic syndrome in adults and is caused by the formation of autoimmune complexes in the glomeruli. Since the identification of different podocyte antigenic targets, the diagnostic strategies and treatment options for MN have significantly improved. The efficacy of rituximab treatment in $\mathrm{MN}$ patients has highlighted the importance of $\mathrm{B}$ cells in the pathogenesis of the disease (113); therefore a more accurate investigation of autoreactive $\mathrm{mBC}$ using new technology may refine current immune-monitoring largely based on the measurement of circulating anti-PLA ${ }_{2} \mathrm{R}$ or antiTHSD7A autoantibodies.

\section{AUTHOR CONTRIBUTIONS}

PC, MJ, AA, ÀF, CC, and OB conceived the article contents, prepared the manuscript, and endorsed the final draft submitted.

\section{FUNDING}

This work was supported by 2 Spanish competitive grants from the Instituto de Salud Carlos III [ICI14/00242; PI16/01321] a FEDER funding way to build Europe. Also, this work was partly supported by the SLT002/16/00183 grant, from the Department of Health of the Generalitat de Catalunya by the call Acció instrumental de programes de recerca orientats en l'àmbit de la recerca i la innovació en salut. We thank the CERCA Programme/Generalitat de Catalunya for the institutional support. OB was awarded with an intensification grant from the Instituto de Salud Carlos III [INT15/00112]. MJ received a research fellowship grant from the Instituto de Salud Carlos III [FI17/00233].
4. Tran TH, Hughes GJ, Greenfeld C, Pham JT. Overview of current and alternative therapies for idiopathic membranous nephropathy. Pharmacotherapy. (2015) 35:396-411. doi: 10.1002/phar.1575

5. Huh H, Lee H, Lee JP, Kim DK, Oh S, Oh YK, et al. Factors affecting the long-term outcomes of idiopathic membranous nephropathy. BMC Nephrol. (2017) 18:104. doi: 10.1186/s12882-017-0525-6

6. Erwin DT, Donadio JV Jr, Holley KE. The clinical course of idiopathic membranous nephropathy. Mayo Clin Proc. (1973) 48:697-712.

7. Schieppati A, Mosconi L, Perna A, Mecca G, Bertani T, Garattini S, Remuzzi G. Prognosis of untreated patients with idiopathic membranous nephropathy. $N$ Engl J Med. (1993) 329:85-9. doi: 10.1056/NEJM199307083290203 
8. Josephson MA, Spargo B, Hollandsworth D, Thistlethwaite JR. The recurrence of recurrent membranous glomerulopathy in a renal transplant recipient: case report and literature review. Am J Kidney Dis. (1994) 24:8738. doi: 10.1016/S0272-6386(12)80685-8

9. Briganti EM, Russ GR, McNeil JJ, Atkins RC, Chadban SJ. Risk of renal allograft loss from recurrent glomerulonephritis. N Engl J Med. (2002) 347:103-9. doi: 10.1056/NEJMoa013036

10. Rodriguez EF, Cosio FG, Nasr SH, Sethi S, Fidler ME, Stegall $\mathrm{MD}$, et al. The pathology and clinical features of early recurrent membranous glomerulonephritis. Am J Transplant. (2012) 12:1029-38. doi: 10.1111/j.1600-6143.2011.03903.x

11. Cosio FG, Cattran DC. Recent advances in our understanding of recurrent primary glomerulonephritis after kidney transplantation. Kidney Int. (2017) 91:304-14. doi: 10.1016/j.kint.2016.08.030

12. Uffing A, Perez-Saez MJ, La Manna G, Comai G, Fischman C, Farouk S, et al. A large, international study on post-transplant glomerular diseases: the TANGO project. BMC Nephrol. (2018) 19:229. doi: 10.1186/s12882-018-1025-z

13. Mirza MK, Kim L, Kadambi PV, Chang A, Meehan SM. Membranous nephropathy transplanted in the donor kidney: observations of resolving glomerulopathy in serial allograft biopsies. Nephrol Dial Transplant. (2014) 29:2343-7. doi: 10.1093/ndt/gfu333

14. Filippone EJ, Farber JL. Membranous nephropathy in the kidney allograft. Clin Transplant. (2016) 30:1394-402. doi: 10.1111/ctr.12847

15. Heymann W, Hackel DB, Harwood S, Wilson SG, Hunter JL. Production of nephrotic syndrome in rats by Freund's adjuvants and rat kidney suspensions. Proc Soc Exp Biol Med. (1959) 100:660-4. doi: 10.3181/00379727-100-24736

16. Salant DJ, Belok S, Madaio MP, Couser WG. A new role for complement in experimental membranous nephropathy in rats. J Clin Invest. (1980) 66:1339-50. doi: 10.1172/JCI109987

17. Doi T, Mayumi M, Kanatsu K, Suehiro F, Hamashima Y. Distribution of IgG subclasses in membranous nephropathy. Clin Exp Immunol. (1984) 58:5762.

18. Kusunoki Y, Itami N, Tochimaru H, Takekoshi Y, Nagasawa S, Yoshiki T. Glomerular deposition of C4 cleavage fragment (C4d) and C4-binding protein in idiopathic membranous glomerulonephritis. Nephron. (1989) 51:17-9. doi: 10.1159/000185234

19. Quigg RJ, Holers VM, Morgan BP, Sneed AE III. Crry and CD59 regulate complement in rat glomerular epithelial cells and are inhibited by the nephritogenic antibody of passive Heymann nephritis. I Immunol. (1995) 154:3437-43.

20. Ma H, Sandor DG, Beck LH Jr. The role of complement in membranous nephropathy. Semin Nephrol. (2013) 33:531-42. doi: 10.1016/j.semnephrol.2013.08.004

21. Mellors RC, Ortega LG. Analytical pathology. III. New observations on the pathogenesis of glomerulonephritis, lipid nephrosis, periarteritis nodosa, and secondary amyloidosis in man. Am J Pathol. (1956) 32:455-99.

22. Movat HZ, Mc GD. The fine structure of the glomerulus in membranous glomerulonephritis (lipoid nephrosis) in adults. Am J Clin Pathol. (1959) 32:109-27. doi: 10.1093/ajcp/32.2.109

23. Mathern DR, Heeger PS. Molecules great and small: the complement system. Clin J Am Soc Nephrol. (2015) 10:1636-50. doi: 10.2215/CJN.062 30614

24. Debiec H, Guigonis V, Mougenot B, Decobert F, Haymann JP, Bensman $A$, et al. Antenatal membranous glomerulonephritis due to antineutral endopeptidase antibodies. N Engl J Med. (2002) 346:2053-60. doi: 10.1056/NEJMoa012895

25. Debiec H, Nauta J, Coulet F, van der Burg M, Guigonis V, Schurmans $\mathrm{T}$, et al. Role of truncating mutations in MME gene in fetomaternal alloimmunisation and antenatal glomerulopathies. Lancet. (2004) 364:12529. doi: 10.1016/S0140-6736(04)17142-0

26. Beck LH Jr, Bonegio RG, Lambeau G, Beck DM, Powell DW, Cummins $\mathrm{TD}$, et al. M-type phospholipase A2 receptor as target antigen in idiopathic membranous nephropathy. N Engl J Med. (2009) 361:11-21. doi: 10.1056/NEJMoa0810457

27. Tomas NM, Beck LH Jr, Meyer-Schwesinger C, Seitz-Polski B, Ma $\mathrm{H}$, Zahner G, et al. Thrombospondin type-1 domain-containing 7A in idiopathic membranous nephropathy. N Engl J Med. (2014) 371:2277-87. doi: 10.1056/NEJMoa1409354

28. Debiec H, Ronco P. PLA2R autoantibodies and PLA2R glomerular deposits in membranous nephropathy. N Engl J Med. (2011) 364:689-90. doi: 10.1056/NEJMc1011678

29. Tomas NM, Hoxha E, Reinicke AT, Fester L, Helmchen U, Gerth J, et al. Autoantibodies against thrombospondin type 1 domain-containing 7A induce membranous nephropathy. J Clin Invest. (2016) 126:2519-32. doi: 10.1172/JCI85265

30. Du Y, Li J, He F, Lv Y, Liu W, Wu P, et al. The diagnosis accuracy of PLA2R$\mathrm{AB}$ in the diagnosis of idiopathic membranous nephropathy: a meta-analysis. PLoS ONE. (2014) 9:e104936. doi: 10.1371/journal.pone.0104936

31. Iwakura T, Ohashi N, Kato A, Baba S, Yasuda H. Prevalence of enhanced granular expression of thrombospondin type-1 domain-containing 7A in the glomeruli of japanese patients with idiopathic membranous nephropathy. PLoS ONE. (2015) 10:e0138841. doi: 10.1371/journal.pone.0138841

32. Larsen CP, Cossey LN, Beck LH. THSD7A staining of membranous glomerulopathy in clinical practice reveals cases with dual autoantibody positivity. Mod Pathol. (2016) 29:421-6. doi: 10.1038/modpathol.2016.32

33. Sethi S, Madden BJ, Debiec H, Charlesworth MC, Gross L, Ravindran A, et al. Exostosin 1/exostosin 2-associated membranous nephropathy. J Am Soc Nephrol. (2019) 30:1123-36. doi: 10.1681/ASN.2018080852

34. Ronco P, Debiec H. Pathophysiological advances in membranous nephropathy: time for a shift in patient's care. Lancet. (2015) 385:1983-92. doi: 10.1016/S0140-6736(15)60731-0

35. Cohen CD, Calvaresi N, Armelloni S, Schmid H, Henger A, Ott U, et al. CD20-positive infiltrates in human membranous glomerulonephritis. $J$ Nephrol. (2005) 18:328-33.

36. Cravedi P, Sghirlanzoni MC, Marasa M, Salerno A, Remuzzi G, Ruggenenti $P$. Efficacy and safety of rituximab second-line therapy for membranous nephropathy: a prospective, matched-cohort study. Am J Nephrol. (2011) 33:461-8. doi: 10.1159/000327611

37. Barrett C, Willcocks LC, Jones RB, Tarzi RM, Henderson RB, Cai G, et al. Effect of belimumab on proteinuria and anti-phospholipase A2 receptor autoantibody in primary membranous nephropathy. Nephrol Dial Transplant. (2019) gfz086. doi: 10.1093/ndt/gfz086. [Epub ahead of print].

38. Fervenza FC, Appel GB, Barbour SJ, Rovin BH, Lafayette RA, Aslam N, et al. Rituximab or cyclosporine in the treatment of membranous nephropathy. $N$ Engl J Med. (2019) 381:36-46. doi: 10.1056/NEJMoa1814427

39. Floege J, Barbour SJ, Cattran DC, Hogan JJ, Nachman PH, Tang SCW, et al. Management and treatment of glomerular diseases (part 1): conclusions from a Kidney Disease: Improving Global Outcomes (KDIGO) controversies conference. Kidney Int. (2019) 95:268-80. doi: 10.1016/j.kint.2018.10.018

40. An C, Akankwasa G, Liu J, Wang D, Cheng G, Zhang J, et al. Urine markers of renal tubular injury in idiopathic membranous nephropathy: a cross sectional study. Clin Chim Acta. (2019) 492:7-11. doi: 10.1016/j.cca.2019.01.015

41. Bobart SA, De Vriese AS, Pawar AS, Zand L, Sethi S, Giesen C, et al. Non-invasive diagnosis of primary membranous nephropathy using phospholipase A2 receptor antibodies. Kidney Int. (2019) 95:429-38. doi: 10.1016/j.kint.2018.10.021

42. Beck LH Jr. PLA2R and THSD7A: disparate paths to the same disease? J Am Soc Nephrol. (2017) 28:2579-89. doi: 10.1681/ASN.2017020178

43. Hoxha E, Beck LH Jr, Wiech T, Tomas NM, Probst C, Mindorf $\mathrm{S}$, et al. An indirect immunofluorescence method facilitates detection of thrombospondin type 1 domain-containing 7A-specific antibodies in membranous nephropathy. $j$ Am Soc Nephrol. (2017) 28:520-31. doi: 10.1681/ASN.2016010050

44. Zaghrini C, Seitz-Polski B, Justino J, Dolla G, Payre C, Jourde-Chiche $\mathrm{N}$, et al. Novel ELISA for thrombospondin type 1 domain-containing 7A autoantibodies in membranous nephropathy. Kidney Int. (2019) 95:666-79. doi: 10.1016/j.kint.2018.10.024

45. Zhang C, Zhang M, Chen D, Ren Q, Xu W, Zeng C, et al. Features of phospholipase $\mathrm{A} 2$ receptor and thrombospondin type-1 domain-containing 7A in malignancy-associated membranous nephropathy. J Clin Pathol. (2019) 72:705-11. doi: 10.1136/jclinpath-2019-205852

46. East L, Isacke CM. The mannose receptor family. Biochim Biophys Acta. (2002) 1572:364-86. doi: 10.1016/S0304-4165(02)00319-7 
47. Zvaritch E, Lambeau G, Lazdunski M. Endocytic properties of the M-type $180-\mathrm{kDa}$ receptor for secretory phospholipases A2. J Biol Chem. (1996) 271:250-7. doi: 10.1074/jbc.271.1.250

48. Yokota Y, Higashino K, Nakano K, Arita H, Hanasaki K. Identification of group $\mathrm{X}$ secretory phospholipase $\mathrm{A}(2)$ as a natural ligand for mouse phospholipase A(2) receptor. FEBS Lett. (2000) 478:187-91. doi: 10.1016/S0014-5793(00)01848-2

49. Silliman CC, Moore EE, Zallen G, Gonzalez R, Johnson JL, Elzi DJ, et al. Presence of the M-type sPLA(2) receptor on neutrophils and its role in elastase release and adhesion. Am J Physiol Cell Physiol. (2002) 283:C110213. doi: 10.1152/ajpcell.00608.2001

50. Ancian P, Lambeau G, Mattei MG, Lazdunski M. The human 180-kDa receptor for secretory phospholipases A2. Molecular cloning, identification of a secreted soluble form, expression, and chromosomal localization. J Biol Chem. (1995) 270:8963-70. doi: 10.1074/jbc.270.15.8963

51. Fresquet M, Jowitt TA, Gummadova J, Collins R, O'Cualain R, McKenzie EA, et al. Identification of a major epitope recognized by PLA2R autoantibodies in primary membranous nephropathy. J Am Soc Nephrol. (2015) 26:302-13. doi: 10.1681/ASN.2014050502

52. Kao L, Lam V, Waldman M, Glassock RJ, Zhu Q. Identification of the immunodominant epitope region in phospholipase A2 receptor-mediating autoantibody binding in idiopathic membranous nephropathy. J Am Soc Nephrol. (2015) 26:291-301. doi: 10.1681/ASN.2013121315

53. Fresquet M, Rhoden SJ, Jowitt TA, McKenzie EA, Roberts I, Lennon R, et al. Autoantigens PLA2R and THSD7A in membranous nephropathy share a common epitope motif in the N-terminal domain. J Autoimmun. (2019) 2019:102308. doi: 10.1016/j.jaut.2019.102308

54. Klouda PT, Manos J, Acheson EJ, Dyer PA, Goldby FS, Harris R, et al. Strong association between idiopathic membranous nephropathy and HLA-DRW3. Lancet. (1979) 2:770-1. doi: 10.1016/S0140-6736(79)92118-4

55. Scolari F, Amoroso A, Savoldi S, Borelli I, Valzorio B, Costantino E, et al. Familial membranous nephropathy. J Nephrol. (1998) 11:35-9.

56. Stanescu HC, Arcos-Burgos M, Medlar A, Bockenhauer D, Kottgen A, Dragomirescu L, et al. Risk HLA-DQA1 and PLA(2)R1 alleles in idiopathic membranous nephropathy. N Engl J Med. (2011) 364:616-26. doi: 10.1056/NEJMoa1009742

57. Lv J, Hou W, Zhou X, Liu G, Zhou F, Zhao N, et al. Interaction between PLA2R1 and HLA-DQA1 variants associates with anti-PLA2R antibodies and membranous nephropathy. J Am Soc Nephrol. (2013) 24:1323-9. doi: 10.1681/ASN.2012080771

58. Bullich G, Ballarin J, Oliver A, Ayasreh N, Silva I, Santin S, et al. HLA-DQA1 and PLA2R1 polymorphisms and risk of idiopathic membranous nephropathy. Clin J Am Soc Nephrol. (2014) 9:335-43. doi: 10.2215/CJN.05310513

59. Saeed M, Beggs ML, Walker PD, Larsen CP. PLA2R-associated membranous glomerulopathy is modulated by common variants in PLA2R1 and HLADQA1 genes. Genes Immun. (2014) 15:556-61. doi: 10.1038/gene.2014.50

60. Ramachandran R, Kumar V, Kumar A, Yadav AK, Nada R, Kumar H, et al. PLA2R antibodies, glomerular PLA2R deposits and variations in PLA2R1 and HLA-DQA1 genes in primary membranous nephropathy in South Asians. Nephrol Dial Transplant. (2016) 31:1486-93. doi: 10.1093/ndt/gfv399

61. Sekula P, Li Y, Stanescu HC, Wuttke M, Ekici AB, Bockenhauer D, et al. Genetic risk variants for membranous nephropathy: extension of and association with other chronic kidney disease aetiologies. Nephrol Dial Transplant. (2017) 32:325-32. doi: 10.1093/ndt/gfw001

62. Cui Z, Xie LJ, Chen FJ, Pei ZY, Zhang LJ, Qu Z, et al. MHC class II risk alleles and amino acid residues in idiopathic membranous nephropathy. J Am Soc Nephrol. (2017) 28:1651-64. doi: 10.1681/ASN.2016020114

63. Le WB, Shi JS, Zhang T, Liu L, Qin HZ, Liang S, et al. HLA-DRB1*15:01 and HLA-DRB3*02:02 in PLA2R-related membranous nephropathy. J Am Soc Nephrol. (2017) 28:1642-50. doi: 10.1681/ASN.2016060644

64. Wang HY, Cui Z, Xie LJ, Zhang LJ, Pei ZY, Chen FJ, et al. HLA class II alleles differing by a single amino acid associate with clinical phenotype and outcome in patients with primary membranous nephropathy. Kidney Int. (2018) 94:974-82. doi: 10.1016/j.kint.2018.06.005

65. Bomback AS, Gharavi AG. Can genetics risk-stratify patients with membranous nephropathy? J Am Soc Nephrol. (2013) 24:1190-2. doi: 10.1681/ASN.2013060576
66. Mladkova N, Kiryluk K. Genetic complexities of the HLA region and idiopathic membranous nephropathy. J Am Soc Nephrol. (2017) 28:1331-4. doi: 10.1681/ASN.2017030283

67. De Vriese AS, Glassock RJ, Nath KA, Sethi S, Fervenza FC. A proposal for a serology-based approach to membranous nephropathy. J Am Soc Nephrol. (2017) 28:421-30. doi: 10.1681/ASN.2016070776

68. Hoxha E, Kneissler U, Stege G, Zahner G, Thiele I, Panzer U, et al. Enhanced expression of the M-type phospholipase A2 receptor in glomeruli correlates with serum receptor antibodies in primary membranous nephropathy. Kidney Int. (2012) 82:797-804. doi: 10.1038/ki.2012.209

69. Svobodova B, Honsova E, Ronco P, Tesar V, Debiec H. Kidney biopsy is a sensitive tool for retrospective diagnosis of PLA2R-related membranous nephropathy. Nephrol Dial Transplant. (2013) 28:1839-44. doi: $10.1093 / \mathrm{ndt} / \mathrm{gfs} 439$

70. Ramachandran R, Kumar V, Nada R, Jha V. Serial monitoring of anti-PLA2R in initial PLA2R-negative patients with primary membranous nephropathy. Kidney Int. (2015) 88:1198-9. doi: 10.1038/ki.2015.310

71. Behnert A, Schiffer M, Muller-Deile J, Beck LH Jr, Mahler M, Fritzler MJ. Antiphospholipase A(2) receptor autoantibodies: a comparison of three different immunoassays for the diagnosis of idiopathic membranous nephropathy. J Immunol Res. (2014) 2014:143274. doi: 10.1155/2014/143274

72. Hofstra JM, Debiec H, Short CD, Pelle T, Kleta R, Mathieson PW, et al. Antiphospholipase A2 receptor antibody titer and subclass in idiopathic membranous nephropathy. J Am Soc Nephrol. (2012) 23:1735-43. doi: 10.1681/ASN.2012030242

73. Timmermans SA, Damoiseaux JG, Heerings-Rewinkel PT, Ayalon R, Beck LH Jr, Schlumberger W, et al. Evaluation of anti-PLA2R1 as measured by a novel ELISA in patients with idiopathic membranous nephropathy: a cohort study. Am J Clin Pathol. (2014) 142:29-34. doi: 10.1309/AJCP8QMOY5GLRSFP

74. Jullien P, Seitz Polski B, Maillard N, Thibaudin D, Laurent B, Ollier E, et al. Anti-phospholipase A2 receptor antibody levels at diagnosis predicts spontaneous remission of idiopathic membranous nephropathy. Clin Kidney J. (2017) 10:209-14. doi: 10.1093/ckj/sfw121

75. Rodas LM, Matas-Garcia A, Barros X, Blasco M, Vinas O, Llobell A, et al. Antiphospholipase 2 receptor antibody levels to predict complete spontaneous remission in primary membranous nephropathy. Clin Kidney J. (2019) 12:36-41. doi: 10.1093/ckj/sfy005

76. Beck LH Jr, Fervenza FC, Beck DM, Bonegio RG, Malik FA, Erickson SB, et al. Rituximab-induced depletion of anti-PLA2R autoantibodies predicts response in membranous nephropathy. J Am Soc Nephrol. (2011) 22:154350. doi: 10.1681/ASN.2010111125

77. Ruggenenti P, Debiec H, Ruggiero B, Chianca A, Pelle T, Gaspari F, et al. Anti-phospholipase A2 receptor antibody titer predicts post-rituximab outcome of membranous nephropathy. J Am Soc Nephrol. (2015) 26:254558. doi: 10.1681/ASN.2014070640

78. Ramachandran R, Yadav AK, Kumar V, Inamdar N, Nada R, Gupta KL, et al. Temporal association between PLA2R antibodies and clinical outcomes in primary membranous nephropathy. Kidney Int Rep. (2018) 3:142-7. doi: 10.1016/j.ekir.2017.09.001

79. Beck LH Jr, Salant DJ. Membranous nephropathy: recent travels and new roads ahead. Kidney Int. (2010) 77:765-70. doi: 10.1038/ki.2010.34

80. Hofstra JM, Beck LH Jr, Beck DM, Wetzels JF, Salant DJ. Anti-phospholipase $\mathrm{A}(2)$ receptor antibodies correlate with clinical status in idiopathic membranous nephropathy. Clin J Am Soc Nephrol. (2011) 6:1286-91. doi: 10.2215/CJN.07210810

81. Qin W, Beck LH Jr, Zeng C, Chen Z, Li S, Zuo K, et al. Anti-phospholipase A2 receptor antibody in membranous nephropathy. J Am Soc Nephrol. (2011) 22:1137-43. doi: 10.1681/ASN.2010090967

82. Radice A, Trezzi B, Maggiore U, Pregnolato F, Stellato T, Napodano $\mathrm{P}$, et al. Clinical usefulness of autoantibodies to M-type phospholipase A2 receptor (PLA2R) for monitoring disease activity in idiopathic membranous nephropathy (IMN). Autoimmun Rev. (2016) 15:146-54. doi: 10.1016/j.autrev.2015.10.004

83. Qu Z, Zhang MF, Cui Z, Wang J, Wang M, Zhang YM, et al. Antibodies against $\mathrm{M}$-type phospholipase A2 receptor may predict treatment response and outcome in membranous nephropathy. Am J Nephrol. (2018) 48:438-46. doi: $10.1159 / 000494662$ 
84. Chen JL, Hu SY, Jia XY, Zhao J, Yang R, Cui Z, et al. Association of epitope spreading of antiglomerular basement membrane antibodies and kidney injury. Clin J Am Soc Nephrol. (2013) 8:51-8. doi: 10.2215/CJN.05140512

85. Cornaby C, Gibbons L, Mayhew V, Sloan CS, Welling A, Poole BD. B cell epitope spreading: mechanisms and contribution to autoimmune diseases. Immunol Lett. (2015) 163:56-68. doi: 10.1016/j.imlet.2014.11.001

86. Seitz-Polski B, Dolla G, Payre C, Girard CA, Polidori J, Zorzi K, et al. Epitope spreading of autoantibody response to PLA2R associates with poor prognosis in membranous nephropathy. J Am Soc Nephrol. (2016) 27:151733. doi: 10.1681/ASN.2014111061

87. Dahan K, Debiec H, Plaisier E, Cachanado M, Rousseau A, Wakselman $\mathrm{L}$, et al. Rituximab for severe membranous nephropathy: a 6-month trial with extended follow-up. J Am Soc Nephrol. (2017) 28:348-58. doi: 10.1681/ASN.2016040449

88. Seitz-Polski B, Debiec H, Rousseau A, Dahan K, Zaghrini C, Payre C, et al. Phospholipase A2 receptor 1 epitope spreading at baseline predicts reduced likelihood of remission of membranous nephropathy. J Am Soc Nephrol. (2018) 29:401-8. doi: 10.1681/ASN.2017070734

89. Ozaki T, Tomino Y, Nakayama S, Koide H. Two-color analysis of lymphocyte subpopulations in patients with nephrotic syndrome due to membranous nephropathy. Clin Nephrol. (1992) 38:75-80.

90. Wang B, Zuo K, Wu Y, Huang Q, Qin WS, Zeng CH, et al. Correlation between B lymphocyte abnormality and disease activity in patients with idiopathic membranous nephropathy. J Int Med Res. (2011) 39:86-95. doi: $10.1177 / 147323001103900111$

91. Cagnoli L, Tabacchi P, Pasquali S, Cenci M, Sasdelli M, Zucchelli P. T cell subset alterations in idiopathic glomerulonephritis. Clin Exp Immunol. (1982) 50:70-6.

92. Zucchelli P, Ponticelli C, Cagnoli L, Aroldi A, Beltrandi E. Prognostic value of T lymphocyte subset ratio in idiopathic membranous nephropathy. Am J Nephrol. (1988) 8:15-20. doi: 10.1159/000167547

93. Taube D, Brown Z, Williams DG. Impaired lymphocyte and suppressor cell function in minimal change nephropathy, membranous nephropathy and focal glomerulosclerosis. Clin Nephrol. (1984) 22:176-82.

94. Hirayama K, Ebihara I, Yamamoto S, Kai H, Muro K, Yamagata K, et al. Predominance of type-2 immune response in idiopathic membranous nephropathy. Cytoplasmic cytokine analysis. Nephron. (2002) 91:255-61. doi: $10.1159 / 000058401$

95. Masutani K, Taniguchi M, Nakashima H, Yotsueda H, Kudoh Y, Tsuruya $\mathrm{K}$, et al. Up-regulated interleukin-4 production by peripheral T-helper cells in idiopathic membranous nephropathy. Nephrol Dial Transplant. (2004) 19:580-6. doi: 10.1093/ndt/gfg572

96. Kuroki A, Iyoda M, Shibata T, Sugisaki T. Th2 cytokines increase and stimulate B cells to produce IgG4 in idiopathic membranous nephropathy. Kidney Int. (2005) 68:302-10. doi: 10.1111/j.1523-1755.2005.00415.x

97. Fervenza FC, Abraham RS, Erickson SB, Irazabal MV, Eirin A, Specks U, et al. Rituximab therapy in idiopathic membranous nephropathy: a 2-year study. Clin J Am Soc Nephrol. (2010) 5:2188-98. doi: 10.2215/CJN.05080610

98. Roccatello D, Sciascia S, Di Simone D, Solfietti L, Naretto C, Fenoglio $\mathrm{R}$, et al. New insights into immune mechanisms underlying response to Rituximab in patients with membranous nephropathy: a prospective study and a review of the literature. Autoimmun Rev. (2016) 15:529-38. doi: 10.1016/j.autrev.2016.02.014

99. Rosenzwajg M, Languille E, Debiec H, Hygino J, Dahan K, Simon T, et al. B- and T-cell subpopulations in patients with severe idiopathic membranous nephropathy may predict an early response to rituximab. Kidney Int. (2017) 92:227-37. doi: 10.1016/j.kint.2017.01.012

100. Noris M, Casiraghi F, Todeschini M, Cravedi P, Cugini D, Monteferrante G, et al. Regulatory $\mathrm{T}$ cells and $\mathrm{T}$ cell depletion: role of immunosuppressive drugs. J Am Soc Nephrol. (2007) 18:1007-18. doi: 10.1681/ASN.2006 101143

101. Wing K, Sakaguchi S. Regulatory $\mathrm{T}$ cells exert checks and balances on self tolerance and autoimmunity. Nat Immunol. (2010) 11:7-13. doi: 10.1038/ni. 1818

102. Remuzzi G, Chiurchiu C, Abbate M, Brusegan V, Bontempelli M, Ruggenenti P. Rituximab for idiopathic membranous nephropathy. Lancet. (2002) 360:923-4. doi: 10.1016/S0140-6736(02)11042-7

103. Bomback AS, Derebail VK, McGregor JG, Kshirsagar AV, Falk RJ, Nachman PH. Rituximab therapy for membranous nephropathy: a systematic review. Clin J Am Soc Nephrol. (2009) 4:734-44. doi: 10.2215/CJN.05231008

104. Ruggenenti P, Cravedi P, Chianca A, Perna A, Ruggiero B, Gaspari F, et al. Rituximab in idiopathic membranous nephropathy. J Am Soc Nephrol. (2012) 23:1416-25. doi: 10.1681/ASN.2012020181

105. Rawlings DJ, Metzler G, Wray-Dutra M, Jackson SW. Altered B cell signalling in autoimmunity. Nat Rev Immunol. (2017) 17:421-36. doi: 10.1038/nri.2017.24

106. Lebrun C, Cohen M, Rosenthal-Allieri MA, Bresch S, Benzaken S, Marignier R, et al. Only follow-up of memory B cells helps monitor rituximab administration to patients with neuromyelitis optica spectrum disorders. Neurol Ther. (2018) 7:373-83. doi: 10.1007/s40120018-0101-4

107. Bauer T, Jilg W. Hepatitis B surface antigen-specific $\mathrm{T}$ and B cell memory in individuals who had lost protective antibodies after hepatitis $\mathrm{B}$ vaccination. Vaccine. (2006) 24:572-7. doi: 10.1016/j.vaccine.2005.08.058

108. Han M, Rogers JA, Lavingia B, Stastny P. Peripheral blood B cells producing donor-specific HLA antibodies in vitro. Hum Immunol. (2009) 70:29-34. doi: 10.1016/j.humimm.2008.10.013

109. Heidt S, Roelen DL, de Vaal YJ, Kester MG, Eijsink C, Thomas S, et al. A NOVel ELISPOT assay to quantify HLA-specific B cells in HLA-immunized individuals. Am J Transplant. (2012) 12:1469-78. doi: $10.1111 / j .1600-6143.2011 .03982 . x$

110. Lucia M, Luque S, Crespo E, Melilli E, Cruzado JM, Martorell J, et al. Preformed circulating HLA-specific memory B cells predict high risk of humoral rejection in kidney transplantation. Kidney Int. (2015) 88:874-87. doi: 10.1038/ki.2015.205

111. Luque S, Lucia M, Melilli E, Lefaucheur C, Crespo M, Loupy A, et al. Value of monitoring circulating donor-reactive memory $\mathrm{B}$ cells to characterize antibody-mediated rejection after kidney transplantation. Am J Transplant. (2019) 19:368-80. doi: 10.1111/ajt.15055

112. Luque S, Lúcia M, Crespo E, Jarque M, Grinyó JM, Bestard O. A multicolour HLA-specific B-cell FluoroSpot assay to functionally track circulating HLA-specific memory B cells. J Immunol Methods. (2018) 462:23-33. doi: 10.1016/j.jim.2018.07.011

113. Cravedi P, Remuzzi G, Ruggenenti P. Rituximab in primary membranous nephropathy: first-line therapy, why not? Nephron Clin Pract. (2014) 128:261-9. doi: 10.1159/000368589

Conflict of Interest: The authors declare that the research was conducted in the absence of any commercial or financial relationships that could be construed as a potential conflict of interest.

Copyright $\odot 2019$ Cravedi, Jarque, Angeletti, Favà, Cantarelli and Bestard. This is an open-access article distributed under the terms of the Creative Commons Attribution License (CC BY). The use, distribution or reproduction in other forums is permitted, provided the original author(s) and the copyright owner(s) are credited and that the original publication in this journal is cited, in accordance with accepted academic practice. No use, distribution or reproduction is permitted which does not comply with these terms. 